\title{
ISLAM AND MINORITIES: Managing Identity in Malaysia
}

\author{
Ahmad Suaedy \\ Executive Director of the Wahid Institute, Jakarta; Visiting Research Fellow \\ at The Center for Southeast Asian Studies (CSEAS), Kyoto University
}

\section{Abstract}

The Malaysian general election in March 2008 raised an interesting and new phenomenon. For the first time since independence in 1957, the ruling alliance known as the National Front (Barisan Nasional, BN) failed to secure two thirds of seats in parliament and lost control of five of Malaysia's 13 states. This was due to the challenge presented by the new opposition alliance known as the Alternative Front (Barisan Alternatif, BA) or the People's Alliance (Pakatan Rakyat, PK) which won more than $36 \%$ of seats in parliament and gained control of the five states. In the 2004 election, BN secured the largest ever percentage of seats in parliament with 91\%. What is interesting is that it seems that this significant increase in support for the opposition is due to their offer to change the way minorities and ethnicity is managed. They propose a move from "Bumiputera Supremacy", or affirmative action for the approximately 65\% of "Bumiputera" Malaysians (the rest being largely of Chinese or Indian ethnicity), to "The People's Supremacy", which involves eradicating affirmative action based on ethnicity, basing it instead on need, for instance need due to poverty. This would potentially increase the likelibood of justice and equality for all ethnic or racial groups. This paper connects the phenomenon of change, as seen in the about turn in the results between the 2004 and 2008 elections, to the more global trend in which minorities are standing up to demand their rights in this era of globalization, and to the challenge multiculturalism presents to parts of the Muslim world such as Malaysia. Malaysia, a Muslim majority nation that has formally declared 
Islam the official state religion with Yang di-Pertuan Agong (the King) as Head of the State and symbol of Islam, is one example, though not necessarily representative, of how Islam and Muslims manage minorities and identity or multiculturalism within the process of globalization.

Keywords: Malaysia, minority studies, bumiputera

\section{A. Introduction}

The current wave of democratization and globalization that has spread throughout the world has also brought to attention the position of minorities. ${ }^{1} \mathrm{New}$ ideas concerning nationalism and national identity have emerged, ${ }^{2}$ not only in non-democratic but also liberal democratic countries. ${ }^{3}$ These ideas can be traced back to the 1970s and 1980s when several minority nationalist movements emerged, particularly in authoritarian and communist countries. They successfully demanded independence, self determination, self governance or at least equal treatment. ${ }^{4}$ A number of Muslim minorities in Eastern Europe (the former Soviet Union) and in the Balkans (former Yugoslavia) underwent such an experience, as with those in liberal democratic countries such as France and England. ${ }^{5}$ Things developed quite differently for many minorities in Muslim majority countries or Islamic states. ${ }^{6}$

${ }^{1}$ See Will Kymlicka, Multicultural Citizenship: A Liberal Theory of Minority Rights (Oxford: Oxford University Press, 1995). Also Bhikhu Parekh, Rethinking Multiculturalism: Cultural Diversity and Political Theory, (London: Macmillan Press, 2000). ledge, 1990).

${ }^{2}$ See, Michael Watson (ed.), Contemporary Minority Nationalism (London: Rout-

${ }^{3}$ See for instance Ilan Peleg, Democratizing the Hegemonic State: Political Transformation in the Age of Identity (Cambridge: Cambridge University Press, 2007). See also Chaim Gans, The Limits of Nationalism (Cambridge: Cambridge University, 2003).

${ }^{4}$ Michael Watson, Contemporary Minority Nationalism. See also Peleg, Democratizing the Hegemonic State.

${ }^{5}$ Hugh Poulton and Suha Taji-Farouki (eds.), Muslim Identity and the Balkan State (London, Hurst and Company in Association with the Islamic Council, 1997). See as well Eli Eminov, Turkish and Other Muslim Minorities of Bulgarian (London: Hurst and Company in Association with the Islamic Council, 1997).

${ }^{6}$ See for instance, Ofra Bengio and Gabriel Ben-Dor (ed.), Minorities and the State in the Arab World (Colorado: Lynne Riemer Publishers Inc., 1999); also Mordechai Nisan, Minorities in the Middle East, A History of Struggle and Self-Expression, $2^{\text {nd }}$ ed. (North Carolina: McFarland and Company Inc., 2002); and Maya Shatzmiller (ed.), Nationalism 
In the 1950s and 1960s little attention was paid to minority groups in democratic countries but especially in communist ones. While minority movements in communist states emerged out of oppression and authoritarianism, in liberal democratic states such movements were a result of democratic systems that promoted individual rights to such an extent that collective and community rights were neglected. ${ }^{7}$

Malaysia is a nation that has always been multiracial, multicultural and, in the words of some, an immigrant state. ${ }^{8}$ It is home to many immigrants, largely Chinese and Indian, although many Malays also come from countries like Indonesia, and more recently the Philippines. ${ }^{9}$ Due to similarities in history, culture, religion, language and skin colour, the latter have easily assimilated to the single Malay or bumiputera ethnic identity and religion. This has not been the case for Chinese and Indian immigrants. There are many other groups, including those of Portuguese descent and the indigenous peoples of Sabah and Sarawak both of whom fall into the bumiputera category. ${ }^{10}$

Despite such diversity, Malaysia has formally declared Islam the official state religion with Yang di-Pertuan Agong (the King) as Head of the State and also a symbol of Islam (Article 53 of the Federal Constitution). ${ }^{11}$ The constitution states that all citizens are equal before the law, and guarantees their right to adhere to a religion. Nevertheless, the constitution clearly places the Malay/bumiputera category before all others with the king responsible for ensuring that this be the case. Article 153 (1) reads, "It shall be responsibility of the Yang di-Pertuan Agong to safeguard the special position of the Malays and natives of any of the states of Sabah and Sarawak and the legitimate interests of other

and Minority Identities in Islamic Society (Quebec: McGill-Queen University Press, 2005). ${ }^{7}$ Hugh Poulton, "The Muslim Experience in the Balkan State, 1919-1991," Association for the Study of Nationalities, Nationalist Papers, Vol. 28, No. 1, 2000; Peleg, Democratizing the Hegemonic State.

8 Timothy P. Daniels, Building Cultural Nationalism in Malaysia: Identity, Representation, and Citizenship (New York: Routledge, 2005).

${ }^{9}$ Ibid., pp. 42-87.

${ }^{10}$ Shad Saleem Faruqi, "Affirmative Action Policies and the Constitution," in Richard Mason \& Ariffin Omar (eds.), The 'Bumiputera Policy': Dynamics and Dilemmas (Penang: Penerbit Universiti Sains Malaysia, 2005), p. 42.

${ }^{11}$ Ibid., p. 43. 
communities...". ${ }^{12}$ The management of ethnic difference and minorities in Malaysia is just one possible representation of society and Muslim governance in the context of a multiracial and multicultural society.

Historically Islam has always had a concept for managing minorities, as is apparent from its discourse on dhimmis (non-Muslims in the land of Islam) and harbis (non-Muslims in the land of war) which refers to the division in Islamic law between dàr al-Islam (the land of Islam) and dar al-harb (the land of war). Islamic concepts addressing minorities, both Muslim minorities in non-Muslim states and nonMuslim minorities in Muslim majority states, have existed since the time of the Prophet Muhammad, and were continually developed throughout the expansion of the Islam, the establishment of Islamic kingdoms including the multinational Ottoman Empire in Turkey, right up until today. ${ }^{13}$ It is fascinating to study just how an Islamic state treats minorities in the context of the nation-state in the contemporary world. This paper examines the empirical reality in Malaysia, the plurality and multiculturalism as well as the position of minorities. However, it does not approach the issue through the lens of Islamic law (shari'ah) as is often the case. ${ }^{14}$ This approach, to borrow Mohamed Arkoun's words, tends to lead to a dead end, trapping scholars in a debate about the (non) separation of religion and the state and the non existence of a concept of state in Islam. ${ }^{15}$ Taking an empirical approach, this paper hopes to avoid judgemental attitudes, allowing us to better examine justice and

${ }^{12}$ Ibid.

${ }^{13}$ See Recep Senturk, "Minority Rights in Islam: From Dhimmi to Citizen," in Shireem T Hunter \& Huma Malik, Islam and Human Rights: Advancing A U.S. - Muslim Dialogue (Washington DC: CSIS, 2005), pp. 67-8; also Richard C Martin, "From Dhimmis to Minorities: Shifting Constructions on the non-Muslim Other from Early to Modern Islam" in Maya Shatzmiller (ed.), Nationalism and Minority Identities in Islamic Society (Quebec: McGill-Queen University Press, 2005). For a comprehensive discussion of the concept of the dhimmi in Islamic society written by a Jew, see Bat Ye'or, The Dhimmi: Jews and Christians Under Islam (New Jersey: Associated University Presses, 1985).

${ }^{14}$ The dhimmi concept and its consequences in Islamic law and from a shari'ah perspective are discussed quite comprehensively by Yūsuf al-Qarḍawi, Ghair al-Muslimin fi al-Mujtama' al-Islamy (Cairo: Maktabah Wahabah, 1992); Hasan Al-Mimmy, AblDhimmah fi al-Hadharaty al-Islamiyah (Beirut: Dar al-Arab al-Islamy, 1998).

${ }^{15}$ Mohammed Arkoun, 2002, "Locating Civil Society In Islamic Contexts" in Amyn B Sajoo (ed.), Civil Society in The Muslim World, Contemporary Perspectives (London: I.B. Tauris Publishers, 2002), pp. 35-60. 
social friction and how they influence economic distribution and division of political power.

The reality in Malaysia illustrates the complexity of the situation. What are the consequences of Malaysia, a nation-state in the form of a constitutional Islamic monarchy, developing and managing a concept addressing multiculturalism, multiracialism and minorities? It is hoped that this discussion contributes to intellectual studies on the Islamic experience of modern Muslim societies and their dynamics, specifically in the case of Malaysia. This is by no means a success story about change, rather it is about significant criticism being levelled against a system that has been well established, hegemonic even, for more than 50 years during which it has never been challenged in a meaningful way. It may well be that this develops into a trend in the future in accordance with changes occurring elsewhere in the world.

\section{B. A Changing Malaysia: from "Bumiputera Supremacy" to "Peo- ple's Supremacy"}

For the first time ever, in the general election on 8 March 2008 the ruling party, Barisan Nasional (BN, National Front), which had been in power for more than 50 years was dealt a strong blow by the opposition, which managed to secure a significant percentage of the vote. BN failed to obtain a two thirds majority in the central parliament (a target it has almost always fulfilled), and lost control of four of 13 states. BN consists of at least four main parties that reflect ethnic difference, namely UMNO (the United Malay National Organization) representing ethnic Malays; MCA (the Malayan Chinese Association) and the multiracial Partai Gerakan Rakyat Malaysia (PGRM, Malaysian People's Movement Party), both of which are largely supported by the Chinese; as well as MIC (the Malayan Indian Congress) representing Indians. It also includes several smaller parties local to Sabah and Sarawak. Whereas the opposition, the new coalition Barisan Alternatif (BA, Alternative Front), later known as Pakatan Rakyat (PR, People's Alliance), consists of three parties, Partai Keadilan Rakyat (PKR, People's Justice Party) which is multiracial but tends to be dominated by Malays; DAP (the Democratic Action Party) also multiracial but tending to be dominated by the Chinese; and Partai Islam se-Malaysia (PAS, the Islamic Party of Malaysia) which is based on 
an Islamic ideology and is almost entirely supported by Muslim Malays.

In comparison, in the 2004 election BN secured a record percentage of seats $(91 \%)$ in the central parliament and maintained control over all states with the exception of Kelantan which has been under PAS leadership since 1990. In the same election PKR only secured 1 seat in parliament. Thus in winning only $63.1 \%$ of seats in 2008 not only did BN lose the two thirds majority in parliament, but PKR alone increased its representation from 1 to 31 seats, with the opposition in general securing $36.9 \%$ (up from $9 \%$ in 2004). BN also lost four states, in addition to Kelantan, with Penang, controlled by ethnic Chinese for the last half century, falling into the hands of DAP, and Kedah and Perak joining Kelantan as PAS controlled states (though Perak recently had control of its local parliament usurped in a less than elegant manner by BN). Selangor, the central state home to Malaysia's capital city Kuala Lumpur, and as such the richest and most strategic of states, fell under PKR control. ${ }^{16}$ In addition, PKR took all 5 central parliament seats in of the Federal Territory, but was unable to seize the position of mayor because it is appointed by the Prime Minister, a position still under UMNO-BN control. ${ }^{17}$

What is interesting is that the PR coalition was able to win a phenomenal ${ }^{18}$ percentage of votes because they offered a new concept of managing interethnic relations and minorities, which had, up until this point, been monopolised by BN. Originally known as the NEP (New Economic Policy) in 1971, BN's concept was further developed by Dr Mahathir Mohammad in 1990 to become the NDP (New Development Policy) and then the NVP (New Vision Policy, 2000) otherwise known as Vision 2020. The 1990 change was implemented after the end of the

${ }^{16}$ It must be noted that Anwar Ibrahim himself did not choose to be the candidate for Selangor, but instead chose Permatang Pauh in Penang which is far from the center and was once an UMNO-BN base. See Ooi Kee Beng, "Postscript: Anwar's Path to Power Goes Via Permatang Pauh," in Ooi Kee Beng, Johan Saranananmuttu \& Lee Hock Guan (eds.), March 8 Eclipsing May 13 (Singapore: ISEAS, 2008), pp. 122-6. Anwar's campaign on multiracialism and meritocracy which criticizes $\mathrm{BN}$ and won him $70 \%$ of the vote in Permatang Pauh is also discussed in this article.

${ }^{17}$ For a fairly comprehensive analysis of the 2008 election results, a comparison with the 2004 election results and the political implications, see Ooi Kee Beng et. al., March 8 Eclipsing May 13.

${ }^{18}$ The PR have named the results that brought down BN "A Political Tsunami or A Tectonic Shift". 
20 year time frame set by the original 1971 NEP had passed and it was found that the policy had failed to see bumiputera increase their control of the national economy to $30 \%$, from the mere $1.7 \%$ they controlled in 1971. It was clearly a concept that gave protection to and often involved affirmative action on behalf of Malay or bumiputera citizens over immigrant ethnic groups, especially the Chinese, as the Malays/ bumiputera were considered economically disadvantaged. While the NEP was rather general and oriented towards villages and agrarian society, the NDP placed more focus on industrial and urban development. ${ }^{19} \mathrm{BN}$ still intends to implement the policy as it has yet to reach its target. In fact, it has been 40 years since the policy was formulated, twice the intended time frame, but still less than $20 \%$ of Malaysia's economy is controlled by indigenous Malays. ${ }^{20}$

Anwar Ibrahim, leader of PR, offered a "New Economic Agenda", arguing that the NEP/NDP/NVP and the policy of Malay or bumiputera supremacy was no longer appropriate if Malaysia wanted to compete on both a national and international scale in the current era of democratisation and globalisation. On the national scale, inequality amongst ethnic groups, especially amongst the Malays/bumiputera has only increased. Many Malays have indeed benefited enormously from the policy, with the latest official government data indicating that they control around 19\% or more of the economy. However, Anwar explains, this wealth finds its way largely into the hands of the elite, and the majority of Malays are left with the pickings, if anything at all. This economic inequality between the rich and poor is much larger amongst the Malays than amongst the Chinese or the Indians, though there is much cronyism amongst all elites within BN. This kind of policy and political system, according to Anwar, means that the competitive ability of the Malays / bumiputera and Malaysia in general is very low because the elites within $\mathrm{BN}$ use their power irresponsibly to serve their own interests.

According to Anwar such unhealthy competition has ultimately caused Malaysia to lose its competitive ability internationally, in Asia, and

${ }^{19}$ See Edmund Terence Gomes, "Affirmative Action and Enterprise Development in Malaysia: The Economic Policy, Business Partnership and Inter-Ethnic Relations," in Richard Mason \& Ariffin Omar (eds.), The 'Bumiputera Policy': Dynamic and Dilemmas (Penang: Penerbit Universiti Sains Malaysia, 2005), pp. 69-104.

${ }^{20}$ Ibid. 
more specifically in Southeast Asia. Malaysia, which began development at the same time as Singapore, South Korea, Taiwan and Hong Kong, has been left far behind in terms of economic growth, social security, anti-corruption and especially democracy, which can be measured from the extent to which freedom of opinion and freedom to associate with others is guaranteed. Thus, he continues, Malaysia must exchange its policy of Bumiputera Supremacy with fair competition through meritocracy, open tenders and healthy democracy. The backwardness of the Malays/bumiputera can no longer be viewed purely in terms of Malay ethnicity or a Malay "ethnic approach", but must be seen objectively in terms of the relationship between rich and poor. Affirmative action must be channelled towards all who require it. Bumiputera, Chinese and Indians each have the same problems of poverty and inequality, and as such these problems must be seen as universal. Anwar thus proposes the concept and slogan "People's Supremacy" to replace "Malay/Bumiputera Supremacy". Political recruitment and state projects must be fair, with open tenders that do not favour certain ethnic identities. Malay, Chinese and Indian members of the BN elite can no longer benefit at the expense of non-BN Malays, Chinese and Indians. ${ }^{21}$

It is clear then that the large number of votes that PR secured in the 2008 election (DAP $12.6 \%$, PAS $10.4 \%$ and PKR 14.0\%) represents a demand for reformation of the way in which multiracial relations and minorities are managed. ${ }^{22}$ On the contrary, the chairman of BN's MIC party failed to secure any seats in parliament, ${ }^{23}$ even though no party in the opposition coalition officially represented the Indian vote. Most Indian voters were disillusioned enough after voting for MIC in BN for 50 years only to be ignored under the policy of Malay/Bumiputera Supremacy

${ }^{21}$ All of Anwar Ibrahim's thoughts discussed above were taken from the 12 page A4 sized leaflet "Agenda Ekonomi Malaysia: Gagasan Pembangunan/The Malaysian Economic Agenda: An Idea for Development" that was printed in mass during the election campaign to be distributed to all Malaysian regions. It offers PKR's ideas for reforming and changing Malaysia, which then formed the basis for the PR alliance. I also attended several of Anwar's speeches on various occasions throughout OctoberDecember, both in Kuala Lumpur and in other states.

${ }^{22}$ See Johan Saravanamuttu, "A Tectonic Shift in Malaysian Politics," in Ooi Kee Beng, Johan Saranananmuttu \& Lee Hock Guan (eds.), March 8 Eclipsing May 13, p. 53.

${ }^{23}$ Sammy Vellu, the general head of MIC for 20 years during which he was elected Member of Parliament, lost his seat in parliament during the 2008 election. 
that they shifted their support to Ibrahim's PKR, even though there is no party in the coalition that officially represents the Indian voice. ${ }^{24}$

Nevertheless, a number of scholars and analysts have noted how several new Indian parties independent of MIC have emerged recently, trying to regain control over the Indian vote from UMNO. ${ }^{25}$ It seems voters are no longer satisfied with symbolic representation based on ethnic lines, but are now demanding real results such as substantial economic redistribution. The majority of Chinese also seem to prefer meritocracy and open competition, to the extent that MCA, formally representing ethnic Chinese in the BN coalition, has also experienced a decline in support. PGRM or Gerakan, the other party largely supported by Chinese, had controlled Penang for decades, only to lose it to DAP in 2008. DAP has, at least in Penang, implemented a vision consistent with PR's stance. ${ }^{26}$

Of course the offer of meritocracy and open tenders was not the only factor leading to PR's phenomenal success. Current changes are clearly linked to demands for reformation voiced as early as 1998/1999, at a time when reformation was taking place in other countries in the region such as Indonesia and Thailand. The unfair treatment of Dr Anwar Ibrahim by PM Dr Mahathir Mohammad, which saw the former expelled from UMNO and the government and later thrown into jail, garnered further support for reformation. ${ }^{27}$ At the same time demands were made to remove the draconian acts that threatened reformists, activists and demonstrators and were used to control Anwar and his sympathisers. ${ }^{28}$

${ }^{24}$ Ibid., p. 38.

${ }^{25}$ Interview with Premesh Chandran (ethnic Indian), often known as Prem, CEO of Malaysia Kini.com, a leading independent online media company in Malaysia, 15 December 2009.

${ }^{26}$ Interview with Dr Mansor Othman, Deputy Prime Minister of Penang from PKR, 19 December 2009.

${ }^{27}$ For a complete discussion of the unjust treatment of Anwar Ibrahim see Pawancheek Marican, Anwar on Trial, In the Face of Injustice (Kuala Lumpur: Gerak Budaya Interprise, 2009).

${ }^{28}$ Syed Husin Ali notes that there are several draconian acts including the ISA, Official Secrets Act (OSA), Police Act (PA), Trade Union Act (TUA), and the University and University Colleges Act (UUCA) which limit freedom of expression and freedom to organize, in addition to the Press Law. See Syed Husin Ali, "Introduction: National Unity and Recent Ethnic Conflict," in Syeh Ali Husin Ali, Ethnic Relations in Malaysia: Harmony and Conflict (Kuala Lumpur: SIRD, 2008), p. xi. 
Another factor in PR's success was the inconsistency and weakness of PM Abdullah Badawi's leadership. More commonly known as Pak Lah, he replaced Dr Mahathir Mohamad in 2003, but failed to fulfil election promises for reformation after his win in 2004. Some of the more important policies he promised included openness, eradication of corruption and increased transparency in institutions, especially within the police force. In practice however, his government still enforced the ISA (Internal Security Act) which allowed people to be detained without sufficient evidence for 30 days, even though most civil society movements critical of the government demanded that it be annulled. ${ }^{29}$ Pak Lah only pretended to annul the legislation, while continuing to enforce it very effectively, along with the draconian acts, to allow him to keep Anwar Ibrahim in jail. Eventually however, not long before the 2008 election Anwar Ibrahim was released and was free to contest the election. ${ }^{30}$ Similarly, promises to reform the police force were not kept due to demands from the political elite and police that Pak Lah could not refuse. ${ }^{31}$

While the press did have some freedom during Pak Lah's term, no significant advances were made. Independent mass media and the opposition party experienced many difficulties, and were subject to government intervention. ${ }^{32}$ Freedom of the media is still very limited today. Electronic and print media continue to have to apply for permits and even today barely any independent media companies manage to obtain these permits, with the exception of online media as it has not yet been

${ }^{29}$ Ibid.

${ }^{30}$ See Syeh Husin Ali, "Authoritarian State and Ethnic Violence," in Syed Husin Ali, Ethnic Relations in Malaysia, pp. 76-80. The short time lapse between Anwar Ibrahim's release from jail and his involvement in the election is seen by a number of observers as a primary factor in the widespread sympathy he received and its impact on the election results.

${ }^{31}$ Ibid.

${ }^{32}$ Interview with Fathi Aris Omar, 3 December 2009. Fathi is the senior editor of the independent online media Malaysia Kini.com. Formed in 1998 during the reformation era, it is known for opposing the government in power and was run by reformation activists. Fathi himself is also a reformist who refuses to be associated with political parties, including the opposition party, preferring instead to remain independent. According to Fathi, only online media has escaped government repression through the Press Law, even though Malaysia Kini has been raided by police for publishing reports criticizing the government. 
legally regulated in Malaysia. ${ }^{33}$ These anti-democratic policies helped raise the popularity of Anwar Ibrahim, PKR and the PR alliance.

Another internal factor was the falling out between Pak Lah and Mahathir that came to a head in the lead up to the 2008 election. The split was so serious that Mahathir even announced his resignation from UMNO and demanded that Pak Lah resign as PM and president of UMNO. ${ }^{34}$ Advocates of reformation criticized Pak Lah as not being firm enough and not realising his reformation promises. Meanwhile Malays and those from UMNO regarded him as being too weak, both because he released Anwar and because of his Islam Hadhari concept $\mathrm{t}^{35}$ which they felt did not side strongly enough with the Malays. However Pak Lah's policies and actions represented a middle path in response to PAS's critique and the PAS-UMNO struggle to win over the Muslim-Malay vote, the image of Malaysian Islam on the international stage, and the spirit of change within Malaysia. According to Professor Osman Bakar, deputy CEO of the think tank established by Pak Lah that was responsible for introducing the Islam Hadhari concept (IAIS - International Institute for Advanced Islamic Studies), the concept was presented to the PM as a serious way in which to address the Malaysian crisis, allowing Malaysia to play a larger role on an international level and more specifically in the Muslim world. UMNO, the power behind the government, he explained, accommodates two large NGOs, one representing multiracial and multicultural demands (Aliran), and the other voicing equality of women and pluralism in Islam (Sisters in Islam, SIS). ${ }^{36}$

${ }^{33}$ Interview with Prem, 15 December 2009.

${ }^{34}$ The deep conflict between Dr Mahathir Mohamad and Abdullah Ahmad Badawi (PM at the time) is documented in Nathaniel Tan, Mahathir vs. Abdullab: Covert Wars and Challenged Legacies (Kuala Lumpur: Malaysiakini, 2007).

${ }^{35}$ For a more detailed explanation of "Islam Hadhori" see Mohammad Hashim Kamali, Civilization Renewal: Revisiting the Islam Hadhari Approach (Kuala Lumpur: IAIS, $2^{\text {nd }}$ rev. ed., 2009). Professor M Hashim Kamali is CEO of IAIS, Pak Lah's think tank which came up with the concept of Islam Hadhori as the vision of Malaysian Islam and UMNO.

${ }^{36}$ Osman Bakar, "Malaysian Islam in the Twenty-First Century: The Promise of a Democratic Transformation?” in John L Elposito, John O Voll \& Osman Bakar (eds.), Asian Islam in 21 ${ }^{\text {st }}$ Century (Oxford: Oxford University Press 2008), pp. 81-107. When the two senior organizers and founders of Aliran in Penang were asked for confirmation, both Professor Francis Loh Kok Wah (interviewed 3/11/09), senior 
Pak Lah has also described Islam Hadhari as a response to Islamic parties, especially PAS which tripled its representation in 1999, but noted that the concept also had to deal with demands from his own party to take more conservative measures against PAS and other Islamic parties. Pak Lah said:

"During the General Election in 1999, the Islamic party saw its biggest gains ever. It tripled its representation in parliament and took control of an oil-rich state. Faced with a strengthened Islamist opposition, some in my party - which promotes an inclusive and progressive Islam - had thought that we had to become more Islamist than the opposition. This was of course, a very dangerous slippery slope. I believe that Malaysian political choices were influenced to some extent on the issue of religiosity, but what was more important to the voters were good governance and broad-based economic growth." 37

He even claimed the program was behind his success in the 2004 general election, stating:

"We are confident that Islam Hadhari Approach can help bring Muslims into the modern world and integrate them in the modern economy. Islam Hadhari approach promotes tolerance, understanding, moderation, peace and certainly enlightenment." ${ }^{\prime 3}$

lecturer in politics at USM, and Professor Mustafa K Anuar (interviewed 3/11/09), lecturer in communications at USM, denied that founder and former CEO of Aliran, Dr Chandra Muzaffar, did not join UMNO to represent Aliran, but rather joined as a form of individual activism that went against his commitment to Aliran. Aliran is an NGO for intellectuals and senior activists established in the 1970s and centered in Penang to advocate multiracialism and multiculturalism as a critique against policies that favour the Malay (such as the NEP). For further information on Aliran see wwww. aliran.com. Zaenah Anwar, a senior board member of SIS, also acknowledges SIS's close relationship with UMNO, signified by the fact that Dr Mahathir Mohammad's daughter, Maria Mahathir, is the current SIS Board Coordinator. The organisation primarily struggles for plural Islam and gender equality in Islam. For more information on SIS see www.sis.org.my.

${ }^{37}$ Dato' Seri Ahmadullah Ahmad Badawi (fifth Malaysian PM), "Islam Hadhari in a Multi-Racial Society", in Islam Hadhari Approach Towards a Progressive Islamic Civilisation (Kuala Lumpur: Department of Islamic Development Malaysia (JAKIM), 2007), p. 130.

${ }^{38}$ Ibid., p. 138. 


\section{Islam and Minority Issues: The Malaysian Historical Experience and Contemporary Reality}

As noted above, Muslims have had much experience both as minorities and as majorities within a region. They were initially minorities in Mecca and later when Muslims took flight (bijra) to Abyssinia and Medina, and continued to be in certain regions throughout the establishment of Islamic kingdoms, ${ }^{39}$ through to the modern era. Their experiences differed across time and space. According to Richard Martin, there are two factors that influence implementation of Islamic law in such a context, namely difference of opinions in the various Islamic schools of thought, and social change and the local political situation. Martin writes:

"This brief and partial survey of legal discourse about Muslims living as minorities in non-Muslim lands yields two important conclusions. First, theological differences accounted for some differences among law schools, especially with regard to the lenience or stringency of the requirement to emigrate. Second, historical change and local political conditions also produced new interpretations, even within the same schools. Nonetheless, as supported by premodern legal and historical texts, a high degree of concern existed in predominantly Islamic societies about Muslims living as minorities beyond the reaches of Islamic governance. On the whole, practical considerations of the safety and prosperity of Muslim minorities who were able to practise their religion often determined how the laws were interpreted and applied. ${ }^{40}$

It is much the same for Muslim majorities, which have existed since the agreement that produced the Medina Charter, the most famous example perhaps being the multinational Ottoman Empire in

${ }^{39}$ A comprehensive discussion of Muslims as minorities during the time of the Prophet Muhammad can be found in Muhammad Yasin Mazhar Siddiqi, The Prophet Mubammad S AW: A Role Model for Muslim Minorities, (Leicestershire: The Islamic Foundation, 2006). And for a discussion of Muslim minorities from the perspective of Islamic law in the period after that era and until just before the fall of the Ottoman Empire see Khaled Abou El Fadl, "Islamic Law and Muslim Minorities: The Juristic Discourse on Muslim Minorities from $8^{\text {th }}$ to $17^{\text {th }}$ Century CE / 2th to $11^{\text {th }}$ Century Hijrah," MUIS Occasional Papers Series, Singapore, 2006.

${ }^{40}$ Richard Martin, "From Dhimmis to Minorities," p. 17. See also Abou El Fadl, "Islamic Law and Muslim Minorities". 
Turkey. ${ }^{41}$ During the period of Islamic kingdoms before the Ottoman Empire was established, there was very little meaningful debate from the perspective of Islamic law or figh (jurisprudence) concerning non-Muslim minorities, who were positioned as dhimmis under Muslim supremacy. Later developments however demanded there be discussion over the phenomenon.

Dhimmis are of protected status (al-himāyah) and are treated differently to Muslims, especially over the obligation to pay tax (jizyah), and the restrictions from holding equal political positions to Muslims as well as from serving as soldiers (for ideological reasons). However, they are required to observe the regulations of the Islamic state, are guaranteed freedom to adhere to a religion and to worship in accordance with that religion, and are protected from attack by others. ${ }^{42}$ Dhimmis were divided into two categories. The first, the people of the book (Jews and Christians), had to be treated well and held a special position in religious law and society. ${ }^{43}$ Meanwhile the second, the polytheists, referred to in the Qur'an as mushrik, were forced to submit until they embraced Islam. ${ }^{44}$ Despite this, Qardawi notes that Islam required that Muslims be tolerant (tasammb) of other religions and their beliefs, quoting a verse from the Qur'an that states it is not the task of Muslims to guide (buda) others to believe in or embrace Islam, but rather that guidance is Allah's will (yashäa Allab). ${ }^{45}$ The concept of differentiating between Muslims and infidels (both dhimmis and ḥarbis - non-Muslims residing in där al-ḥarb), which is combined into the concept of där al-Islam (land of Islam) and dàr al-harb (land of war) and even the newer concept of där al-sulh (land of truce), ${ }^{46}$ in essence refers to a concept of Muslim supremacy over all

${ }^{41}$ Bat Ye'or, The Dhimmi. Contrast this with Muhammad Yasin Mazhar Siddiqi, The Prophet Muhammad SAW.

${ }^{42}$ Yūsuf al-Qarḍawi, Ghair al-Muslimin, pp. 6-57. Hasan Al-Mimmy, AblDhimmah fi al-Hadara, pp. 5-50.

${ }^{43}$ Qarḍawi, Ghair al-Muslimin, p. 6 [Qur'an: al-Mumtahanah (8-9), al-Ankabūt (49), and al-Rūm (21)].

${ }^{44}$ Qur'an: al-Taubah/9 [28-29]. See also Martin, "From Dhimmis to Minorities," p. 4. This division eventually led to the emergence of several minority sects within Islam itself. Ibid. p. 7.

${ }^{45}$ Qardawi, Ghair al-Muslimin, p. 49; Qur'an: al-Baqarah/2: 272.

${ }^{46}$ Ismā'il Lutfi al-Fattāni, Ikbtilāf al-Dār wa-Athārubu fìl-Hukm al-Munākahāt wa'l-Mu'āmalāt (Saudi Arabia: Dār as-Salām, 1990), pp. 5-25. 
others within dàr al-Isläm, both constitutionally and in terms of economic and socio-political practices.

In the modern era the concept of nation-state nationalism does not differentiate citizens based on ethnicity, religion, gender, skin colour and so on. Differing from this concept, the Ottoman Empire in Turkey applied the concept of multinationalism, whereby international Islamic hegemony did not lead to universal enforcement of Islamic law for all citizens, but instead drew from the dhimmi concept in application of the Millet concept which allowed each religion the freedom to enforce their own religious laws within their own communities, under the coordination of the Ottoman Empire. ${ }^{47}$ Under this Millet concept, the Ottoman Turks are said to have given significant social, political and economic opportunities to non-Muslim minorities such as the Jews, Christians, Armenians and Greek Orthodox Christians helping them penetrate a number of professions and to hold public roles in finance, diplomacy, industry and public administration. ${ }^{48}$

The emergence of the concept of the nation-state and modern nationalism coinciding with European influence in the East and the fall of the Ottoman Empire destroyed the Millet concept, even in Islamic states. The terms dhimmi and harbi, although still used frequently in discussions on Islamic law on campus and in Islamic study groups, had to be modified in accordance with the developments taking place within society. According to Martin, there are four primary factors that have shaped the concept of minority status in Islam:

“... the determinants of an Islamic vocabulary and concept of minorities were: (1) the contentious power politics of early Islamic expansion; (2) the religious identities that this highlighted and created; (3) such ethnic issues as the significance of Arab Identity in claiming privileges in the Islamic social order; and (4) the message of scripture and the direction given to the Muslim community by the Prophet Muhammad." 49

${ }^{47}$ See Recep Senturk, "Minority Rights in Islam: From Dhimmi to Citizen,” in Shireen T Hunter \& Huma Malik (ed.), Islam and Human Rights: Advancing a U.S. - Muslim Dialogue (Washington D.C.: CSIS, 2005), pp. 68-99.

${ }^{48}$ Mordechai Nisan, Minorities in the Middle East, A History of Struggle and SelfExpression, 2nd ed. (North Carolina: McFarland and Company Inc., 2002), p. 25.

${ }^{49}$ Martin, "From Dhimmis to Minorities," p. 7. 
It is thus clear that this concept/doctrine constantly underwent development and changed in accordance with local socio-political conditions and the demands of society across time and space. Generally speaking there has been one major problem with equality in the relationship between the majority and minorities in Islamic states. Martin writes:

"Within the context of more general theoretical considerations, (...) minority status often involves some form of exclusion from the dominant society or assignment to a lower status in one or more of four areas of life: (1) economics, (2) political, (3) legal, and/or (4) social-associational. Dominance, on the other hand, is based on (1) power, which enables the dominant groups(s) to exploit the minority; (2) ideology, which rationalizes the claims that the dominant group has a monopoly over the minority (for example, Hindus over Muslims in India); and (3) racism, which argues for biological superiority. ${ }^{50}$

There are three general opinions on the dhimmi concept in the modern era, especially concerning its relationship with democracy and human rights. First, there are those who want the concept of the modern nation-state and of universal human rights to realistically accept the dhimmi concept as a concept with a long and valid history, and that is considered by the Muslim community to possess universal truth as it represents divine revelation from God. Although it is not easy to alter the fundamental principles behind the concept of the nation-state and universal human rights, especially in regards to the equality of humans and citizens, this perspective feels that respect of the unique dhimmi concept is important and both strengthens the legitimacy and increases acceptance of human rights.

Timothy William Waters from Indiana University School of Law, Bloomington, is a scholar of this opinion. ${ }^{51}$ Waters writes that human rights currently need more widespread legitimacy, especially from groups within society that hold to concepts that differ from the human rights concept whose roots can be traced back to the tradition of Western

${ }^{50}$ Ibid., p. 14.

${ }^{51}$ Timothy Waters, "Reconsidering Dhimmah as a Model for a Modern Minority Rights Regime (with Some Notes on the Implications for Human Rights)", 30 October 2006, available at http://papers.ssrn.com/sol3/papers.cfm?abstract_id=941553, accessed 06/10/09. The article is said to be published in the forthcoming book by M Habibi Modjandeh (ed.), "Theoretical Foundations of Human Rights". 
liberalism. As we have seen, Islam has its own ideas about minorities as expressed in the dhimmi concept, and this concept has the power to increase legitimacy and acceptance of the concept of universal human rights. ${ }^{52}$ The dhimmi concept, which has historical and religious legitimacy, should be considered as the foundation on which to introduce human rights to the Muslim community in a way that decreases tensions between universal human rights and their relationship with local traditions and religions. According to Waters, this would strengthen the legitimacy of human rights within social and religious groups that have to date opposed the concept on the basis of religious and socio-cultural particularities. Waters acknowledges that there are still several problems within the dhimmi concept, especially concerning inequality of citizens. This is because, he says, the dhimmi concept has tended to be oriented towards allowing different (alien) minority groups the freedom to exist rather than towards ensuring that the state actively protects their rights. Waters writes:

“... It is not a claim about cultural relativism but a model of decisional autonomy, a claim that different polities ought to have broad latitude to construct their own rules. It draws implicitly on the Roman concept of jus gentium, which guarantees, not a right to certain substantive rights, but a right to a system. It is thus a commitment to systemic diversity and particularism - notions that may conflict with the universalizing individual commitments of orthodox human rights." ${ }^{53}$

The second perspective tries to bridge the divide between universal or secular law (particularly human rights) and religious or Islamic law. In support of this view is Recep Senturk, who argues that in the current era of democratisation and pluralism there needs to be an effort made to bridge the divide between secular law, which is considered to be universal, and religious law, in particular Islamic law, which is considered particular. ${ }^{54}$ For Senturk, Islamic law in the European Middle Ages was similar to Christian inspired law in Europe or that of any other religion in the world for that matter. Islamic law basically only regulated the Muslim community, and Islamic kingdoms right through to the Ottoman Empire gave

\footnotetext{
52 Ibid., p. 7.

${ }^{53}$ Ibid., p. 15.

${ }^{54}$ Recep Senturk, "Minority Rights in Islam: From Dhimmi to Citizen,” p. 71.
} 
flexibility for other religious communities to apply their own laws under the protection of Islam. Senturk also states that the reality differs from what is written in the classical Islamic texts or described by Orientalists. That is, in practice Islamic law did not treat people of the book, in this case Jews and Christians, differently from polytheistic religions, at least not in India and Iran. Rather, Islamic kingdoms treated them equally, giving them the freedom to enforce their own religious laws. Only when there were problems between Muslims and non-Muslims was Islamic law involved. In order to prevent clashes between praxis and the text of the Qur'an and Hadith when the two were in contradiction, Muslim jurists placed the concept of al-daruiryyah al-shar'iyyah or "axiom of law" into effect as the method to be used for interpretation. ${ }^{55}$

For Senturk, the long tension that has existed between religious and secular law is a direct result of age old tensions between the two that if maintained will hinder pluralism and democracy. The reality, he continues, is that it is often religious leaders that promote pluralism and democracy, and even protection of minorities. He writes of the need to get beyond tension, by building a bridge between the two laws:

"Traditionally, the answer has been either secularism or religion. Recently a trend has emerged, however, that aims to construct a new framework that would allow combining secular and religious view points on pluralism and democracy. If there is nothing in the religious and secular approach to make them mutually exclusive on their view as to the inviolability of the rights of others, then it seems plausible to allow them to work together with a synergy in promoting pluralism and democracy. With the resurgence of religion everywhere in the world, such an approach may better serve mutual respect." 56

Finally, the third stance involves transformation and reinterpretation of the dhimmi concept so that it becomes a concept for minorities within the context of human rights. Abdullahi Ahmed An-Nai'm has proposed that the concepts of sovereignty and citizenship be used as general principles for reforming Islamic law in this era of modern states and international law. Such a reformation would lead to equality of all individuals and citizens by ignoring differences in religion, gender and

\footnotetext{
${ }^{55}$ Ibid., pp. 68-70.

${ }^{56}$ Ibid. p. 70.
} 
race, and, within the context of Islam, application of Islamic law would not be based on the concept of a purely Muslim community. ${ }^{57}$ According to Na'im, Islamic law must be transformed in a way that it does not discriminate against humans or individuals based on religion or gender. Islamic intellectuals have already proven that although slavery is mentioned in the holy texts and was legitimate in Islamic history, its eradication under Islamic law is also seen as legitimate and as representative of Islamic thinkers. Na'im writes:

"Modern Muslim writers seek to defend Shari'a on all of these features of discrimination against women and dhimmis by citing historical sociological and political justifications. Although the acceptance or rejection of a given justification as valid is a subjective matter, generally prevailing notions of justice and reasonableness have a role to play in the process. For example, whereas slavery may have been accepted as justifiable in the past, no one would claim that it is now. It is my submission that these elements of discrimination against women and non-Muslims cannot be accepted as justifiable by the standards of justice and reasonableness prevailing today." 58

Malaysia has had its own unique experience of these developments in accordance with the distinct Malaysian socio-historic context. However, the reality in Malaysia has at times approached one or more of the three models above, although the term dhimmi is never used. ${ }^{59}$

${ }^{57}$ Abdullahi Ahmed An-Naim, Toward an Islamic Reformation: Civil Liberties, Human Rights, and International Law (New York: Syracuse University Press, 1990), especially pp. 86-91.

${ }^{58}$ Ibid., p. 91.

${ }^{59}$ Interview with a number of well-positioned men, including YB Dato' Hj. Mohd Amar B. Nik Abdullah, deputy chairman of PAS and deputy Prime Minister of Kelantan (28/12/09). Interview with Professor M Hashim Kamali (24/12/09) and Professor Osman Bakar (21/12/09), CEO and deputy CEO of IAIS, both of whom said that the dhimmi issue had never been discussed openly because it was too sensitive. However Husin Mutalib, in Islam Etnisitas: Perspektif Politik Melayu_Ethnic Islam: The Malay Political Perspective] (Jakarta: LP3S, 1995), pp. 103-50, writes that PAS took up the issue after the party's first win in Kelantan in the 1974 election, but that all discussion was from a shari'ah perspective that tended to be judgmental. As such it did not last long as it was considered too sensitive and counterproductive, in addition to being contrary to the government's bumiputera program. PAS then lost Kelantan in the following election. However Husni writes in the same book and in another, Islam in Malaysia: From Revivalism to Islamic State, Singapore, Singapore University Press, 1993, pp. 78-117, that PAS did 


\section{Democratization via Transformation of Ethnic Hegemony: The Malaysian Case}

Liberal democratic states have also had majorities that have held privileged positions if one recalls, for instance, the history of Anglican Christians in Great Britain. They were privileged not only in Great Britain, but also in nearly all liberal European states applying individual rights. The same was true for Protestant Christians in the United States and in Australia. ${ }^{60}$ Anglicans had an official church within the state that even today acts as a reference for those who run the state. The question is, does this privileged position stand in the way of individual access and freedom, or suggest discrimination? If yes, this implies violation of democratic and human rights principles.

Enforcement of individual rights in liberal democracies begs the question, does the guarantee of individual rights interfere with the guarantee of collective or community rights, especially those of minorities within a state? If yes, then the concept of democracy should be questioned and altered in order that guarantee of individual rights does not override guarantee of the collective or community rights of minorities. However, at least according to Will Kymlicka, the desire of minority groups for collective guarantees should not hamper the enforcement of individual rights for their members. Democracy does not condone guaranteeing the collective rights of a group if that group violates the individual rights of its members or puts internal restrictions in place. ${ }^{61}$ Traditional concepts of nationalism, according to Kymlicka, collective rights were not given attention, as focus was primarily on the guarantee of individual rights. In fact, in human rights concepts the matter was not even raised. Kymlicka writes:

"The problem is not that traditional human rights doctrines give

not agree with Bumiputera Supremacy, not over issues with equality in democracy and human rights, but because Islam and Islamic universalism cannot be attributed to just one ethnicity or group. At the same time PAS was advocating Malaysia as an Islamic state with implementation of Islamic Law. See also Fariz A Noor, Islam Embedded: The Historical Development of the Pan-Malaysian Islam Party PAS (1951-2003) [Vol. 1 and 2], Vol. 1 (Kuala Lumpur: Malaysian Sociological Research Institute, 2004).

${ }^{60}$ See Will Kymlicka, Multicultural Citizenship: A Liberal Theory of Minority Rights (Oxford, Clarendon Press, 1995), pp. 53-7.

${ }^{61}$ Ibid., pp. 57-8. 
us the wrong answer to this question [minority rights]. It is rather that they often give no answer at all. The rights to free speech does not tell us what an appropriate language policy is; the right to vote does not tell us how political boundaries should be drawn, or how powers should be distributed between levels of government; the right to mobility does not distinguish between an appropriate immigration and naturalization polity is. These questions have been left to the usual process of majoritarian decision-making within each state." ${ }^{.62}$

Globalisation has led to a new problem in regards to the collective rights of minorities. As with criticism levelled at the dhimmi concept in Islamic or Muslim majority states, criticism of the concept of nation-state nationalism which universalised individual freedoms has also undergone development and change. Chaim Gans, for instance, differentiates between statist nationalism and cultural nationalism. The old concept of nationalism, statist nationalism, tends to place more emphasis on geographical boundaries and national unity of all citizens. Cultural differences are minimized and not considered important. This concept was applied strictly up until the Second World War. ${ }^{63}$ More recently a newer concept known as cultural nationalism has emerged to challenge statist nationalism. It demands all groups marked by unique characteristics and long histories, no matter how small they may be, be granted cultural rights as groups within the nation-state. One of the more extreme examples of this is Quebec's relationship with Canada. It has a unique history and culture, especially with its use of French, and thus Quebec has been granted the right to use a language other than the national language and to promote their traditions as the unique culture of the region, even though the province exists within Canada. ${ }^{64}$ Any state that is historically home to very sharp cultural differences, will find it is necessary to consider application of the concept of cultural nationalism, as statist nationalism has to answer to some profound demands and much criticism in this contemporary era of globalisation.

${ }^{62}$ Ibid., p. 5.

${ }^{63}$ See for instance, Chaim Gans, 2003, The Limits of Nationalism (Cambridge: Cambridge University Press), particularly pp. 7-66.

${ }^{64}$ Michael Macmillan, "Quebec," in Michael Watson (ed.), Contemporary Minority Nationalism (London: Routledge, 1990), pp. 117-145. 
According to Kymlicka, even in liberal democracies very little substantial discussion has emerged over the place of minorities or the guarantee of collective rights for small groups. ${ }^{65}$ Specifically for collective rights, Kymlicka examines immigrants, and their claim to be respected equally with the natives of the country to which they have migrated. He argues that both native and immigrant minorities have the same rights to social, economic and political equality, as well as citizenship. They are only different in that immigrants in general migrate voluntarily, and as such do not have the right to demand self-governance. ${ }^{66}$ In the case of Malaysia, demands to remove the Malay/Bumiputera Supremacy policy came primarily from immigrant groups, particularly the Indian and Chinese communities who felt discriminated against, but were also supported by some ethnic Malays. Together they formed the allied opposition party PR, though each individual party (PKR, PAS and DAP) had their own reasons for wanting the policy removed. The immigrants, as Kymlicka describes, did not intend to establish their own state entity and obtain self-governance, rather they limited their demands to equality in the constitution, work opportunities, and political and economic standing. Although Penang, for instance, has a Chinese majority, they are quite satisfied with the opposition coalition's policy of meritocracy and open tenders. They have never voiced aspirations for separation as in Singapore for instance. Elsewhere, ethnic Chinese and Indians are spread throughout regions, even residing in villages, contrary to the native minorities concentrated in Sabah and Sarawak. Even these indigenous groups have never spoken about autonomy or self-governance, though they have not, by any means, received just economic distribution.

Clearly, Malaysia currently faces a number of issues concerning equality and minority rights, especially for Chinese and Indian immigrants, and economic justice for native minorities even though they are technically classed as bumiputera. This has pushed some scholars to question Malaysia's status as a liberal democracy, given that although the Malaysian constitution guarantees equality of citizens and religious freedom, at the same time it also outlines the idea of Bumiputera Supremacy, and not

${ }^{65}$ Kymlicka, Multicultural Citizenship, p. 53.

${ }^{66}$ Ibid., p. 63. 
solely as an emergency program. ${ }^{67}$ For Peleg there are three criteria a state must meet to be categorised as a liberal democracy: (1) equality of all citizens as individuals, as without this democracy cannot be achieved; (2) equality of most groups within society; even though there may be sharp differences between them that cause several smaller groups to not obtain truly equal recognition there must be a political guarantee that they be accepted and treated equally; (3) equality must be formal and real, legal and practical, in the sense that all individuals have equal opportunities to actively pursue their aspirations. ${ }^{68}$

According to Peleg, a democratic state that still differentiates between citizens based on ethnicity and chooses to give priority to the majority is tantamount to a hegemonic state. ${ }^{69}$ Such states, he continues, are currently facing significant protest and demands from their discriminated or marginalised citizens. Peleg warns that if these demands do not receive a satisfactory response from the status quo and fail to produce any kind of transformation towards better equality, experience shows that violence is often a final resort. ${ }^{70}$ Despite this, minorities in Malaysia have never instigated violence, rather it has been the majority which has done so, most phenomenally in the 1969 election. It is important that these kind of demands for equality that have spread throughout the world not be ignored. The opposition's ability to secure a record breaking number of seats in parliament and control over a number of states in Malaysia for the first time since independence due to the its offer of equality and meritocracy, is an important sign of the desire for real and significant transformation. ${ }^{71}$

\section{E. Managing Minorities and Identity in Malaysia}

\section{A racial approach and immigrant status}

Racial approaches in Malaysian politics have been around since before independence, and were advocated strongly in the struggle for

${ }^{67}$ K S Jomo, "Whither Malaysia’s New Economic Policy?” Pacific Affairs Journal, Vol. 63, No. 4 (Winter, 1990-1991), pp. 469-99.

${ }^{68}$ Ilan Peleg, Democratizing The Hegemonic State, p. 55.

${ }^{69}$ Ibid., pp. 60-5.

${ }^{70}$ Ibid. pp. 68-9.

${ }^{71}$ Ilan Peleg uses the word "transformation" to refer to the change from an ethnic hegemonic state to equality of all citizens. Ibid., p. 68. 
independence. ${ }^{72}$ Their implementation has evolved over time, dating back to European occupation when trade and economic progression in Southeast Asia or the Malay Peninsula led to mass Chinese migration to the region. ${ }^{73}$ By the time Malaysian independence was declared in 1957, and before the inclusion of the Malay majority states of Sabah and Sarawak in 1963 and the separation of the Chinese majority Singapore in 1965, there was almost equal numbers of ethnic Malays and immigrants (Chinese and Indian). On the other hand, unfair treatment by the European/ English and even Japanese colonisers of the ethnic Malays/pribumi saw ethnic Chinese/immigrants progress faster than the natives. ${ }^{74}$ This led to chronic economic inequality. By 1970, 13 years after independence, the pribumi only controlled $1.7 \%$ of the national economy. This led to a general awareness and, after the interracial unrest during the general election on 13 May $1969,{ }^{75}$ a more concerted push for affirmative action.

Within UMNO, the party leading the National Front (BN) coalition, there was internal "conflict" over the government policy which some younger members under the guidance of Dr Mahathir Mohamad felt could have been more pro-Malay. Mahathir's extreme actions saw him marginalised, as the mainstream leadership of UMNO, led by Tunku Abdul Rahman, has since tended to be more moderate. Mahathir wrote the classic book The Malay Dilemma, published in 1970. Though banned

${ }^{72}$ A comprehensive anthropological approach towards identity, ethnicity and the origins of citizens which has implications for the Malaysian model of citizenship and typology, not to mention political system, is presented in Daniels, Building Cultural Nationalism in Malaysia.

${ }^{73}$ See Ariffin Omar, "Origins and Development of the Affirmative Policy in Malaya and Malaysia: A Historical Overview," in Mason \& Ariffin (eds.), The Bumiputera Policy', pp. 13-8.

${ }^{74}$ See Shelia Nair, "Colonialism, Nationalism, Ethnicity: Constructing Identity and Difference," in Lin Tck Ghee, Alberto Gomes, Azly Ramand (eds.), Multiethnic Malaysia: Past, Present and Future (Kuala Lumpur: SIRD, 2009), pp. 77-94. Also Ariffin Omar, "Origins and Development", pp. 13-6.

${ }^{75}$ There has recently been some debate over whether the unrest was a natural grassroots reaction to the inequality or was somehow engineered by an invisible hand. One must remember that at the time the Barisan Nasional alliance under UMNO coordination was defeated convincingly in several electorates and even lost several states which they had previously controlled. Strangely, parties supported by the Chinese won in these regions. See Kua Kia Soong, May 13: Declassified Documents on the Malaysian Riots of 1969 (Kuala Lumpur: Suara Komunikasi, 2007). 
by PM Tunku, the book has inspired the radical movement for a superior Malay policy, which at the time strengthened the affirmative policy, later known as the NEP (New Economic Policy). ${ }^{76}$ The NEP has two main aims, namely eradication of poverty and restructuring of economic equality to ensure that Malays increase control over the national economy to $30 \%$ by 1990 , with $40 \%$ for non-bumiputera and the remaining $30 \%$ for foreign investment. ${ }^{77}$

With reference to the causes and factors behind the 13 May 1969 unrest, Mahathir emphasised that the severe economic disproportion between the pribumi and the immigrants, particularly the Chinese, and the government's unwillingness to take sides had led to the relative backwardness and poverty of the bumiputera. Mahathir also argued that assimilation of Chinese immigrants was only surface deep with no intensive dialogue or cooperation in the economic, social or cultural sectors. Mahatahir compared this with Indian and Arab immigrants who, unlike the dominating Chinese, had helped alter the economic behaviour of Malaysians through their close relationship and entrepreneurship, both in villages and small cities, that had helped both parties progress together. Portuguese, English and even Japanese colonisers, Mahathir continued, only worsened social, cultural and economic inequalities which led to a less than harmonious relationship between the Chinese and Malay pribumi because of the neglect of the latter. Then, he continued, after independence there was much nepotism and collusion such as the "Ali-Baba economy" between the largely Chinese immigrants and the pribumi political elite. Mahathir, once again referring to the 1969 racial unrest, concluded that Malaysia needed strong leadership to make drastic changes in order to remedy economic, social and cultural inequalities. Mahathir also "predicted", to refrain from saying "threatened", that if no significant changes were made to rectify such inequalities between the Malays and the Chinese, then revolution was likely. He writes:

${ }^{76}$ This kind of approach had been implemented since independence, but under PM Tunku Abdul Rahman from this time and up until the racial unrest of 1969, it was felt that the approach had not significantly increased Malay economic control, in part because of corruption and cronyism. See Ariffin Omar, "Origins and Development of the Affirmative Policy in Malaya and Malaysia," in Mason and Ariffin (eds.), The 'Bumiputera Policy', pp. 18-22.

${ }^{77}$ See for instance Jomo, “Whither Malaysia’s New Economic Policy”, pp. 469-99. 
"The events of 13 May 1969 have shown that facts, however unpleasant, must be faced. The people who ran amok on that fateful day were Malays. That sudden outburst has undone almost all that has been achieved over the past twelve years. If we are not to see a repetition of this carnage, it would be as well to know some of the reasons for that unprecedented calamity, and to think seriously about rehabilitating the Malays."

"... It is therefore imperative that a determined attempt be made to solve this dilemma. The first need is a revolution. Revolution is a word which is unduly feared in Malaysia. Revolution creates visions of assassinations and anarchy..."78

Mahathir was highly critical of PM Tunku Abdul Rahman not only in his writing and speeches but also enlisted a number of youth within UMNO to oppose Tunku's policies that Mahathir saw as corrupt, nepotistic and not sufficiently pro-Malay. This led to his sidelining from the UMNO ruling elite and the banning of his book. ${ }^{79}$ However, he was not sidelined for long as his movement successfully forced Tunku to resign and instead take on a role as a Father of the Nation. He was replaced by Tun Abdur Razak in 1972, a move which saw Mahathir take a position once again within the UMNO ruling elite. Razak's term ended when he died in 1976, and he was replaced by his deputy, Hussein Onn. Surprisingly, Onn appointed Mahathir as his deputy, which allowed Mahathir to later take the reigns as PM when Onn's first term ended in 1981. Mahathir became UMNO president, Prime Minister of Malaysia, and as such, leader of the BN coalition. Mahathir book was revised in 1983, two years into Mahathir's term, though the thoughts it espoused had for some years been influencing government policies, most importantly the NEP, formulated and enforced in 1971, and further strengthened when Tun Abdul Razak became PM. Later, Mahathir was to put a more

${ }^{78}$ Mahathir bin Mohamad, The Malay Dilemma (With A New Preface) (Singapore: Matshall Cavendish Editions, 2008), pp. 133-4.

${ }^{79}$ See Ariffin Omar, "Origins and Development", p. 18-9. According to Ariffin, the lack of change in the economic structure between the pribumi and Chinese under Tunku Abdul Rahman was because Tunku was still under the former shadow of English colonizers and because of strong lobbying by the Chinese via their party (MCA) within the $\mathrm{BN}$ coalition. It seems that this was what Mahathir was criticizing for being cronyism and nepotism. See also Jomo, "Whither Malaysia’s New Economic Policy," pp. 469-99. 
extensive and wider reaching NEP policy into effect. ${ }^{80}$

But how does Mahathir view the policy after 40 years of implementation, 22 of which were under his own rule? In the introduction to the 2008 edition of The Malay Dilemma, Mahathir admitted that there had been changes in the composition of economic control and professionalism for the Malays. In terms of economic and technological cooperation, for instance, Malays were relatively on par with the Chinese. However, he continued, changing his convictions would require further research as the issue was complex.

"I had been very critical of Chinese business practices, which seem to keep the Malays out. At the time of writing the book [The Malay Dilemma], the Chinese had not yet taken to the public limited companies. Their businesses were almost all family owned."

"But today most of the big Chinese businesses are listed on the stock exchange... I need to rethink about Chinese business practices and their effect on the Malays. ..."

"I hope to be able to revise The Malay Dilemma at some stage in the future. ...". ${ }^{81}$

In other words, although admitting that significant changes had occurred, Mahathir was yet to revise his views.

Mahathir's ideas and his NEP policy have not escaped criticism and protest, especially from ethnic Chinese and Indians. A successful Chinese businessman, Ye Lin-Sheng, told how after reading Mahathir's book in 1970 he was determined to respond. However, he claimed that although he put pen to paper in 1990, at the time the NEP program was set to end, his book was only published in 2003, after Mahathir Mohamad's replacement by Pak Lah. The title of his book, The Chinese Dilemma, was based on that of Mahathir's but clearly expressed the Chinese perspective. Lin-Sheng, the son of a Chinese immigrant who migrated to Malaysia in the 1930s, is now 70 years old, and owns successful world conglomerate. Lin-Sheng admitted realistically that the NEP had been necessary, and had achieved some fundamental changes, but should not be continued indefinitely as it had already created a wide divide between the pribumi

${ }^{80}$ See Maznah Mohamad, "Politics of the NEP and Ethnic Relations in Malaysia," in Lim Teck Ghee et. al., Multiethnic Malaysia," pp. 128-9.

${ }^{81}$ Mahathir, The Malay Dilemma, p. 5. 
and immigrants, both of whom were equally Malaysian. The program has significantly reduced opportunities available to the Chinese to work and establish businesses, and has led to economic inequalities amongst the Chinese themselves. The application of the NEP, Lin-Sheng said, had led to misuse and abuse of power, even amongst the Chinese between those affiliated with MCA and all others. He writes:

“... the MCA's role has been reduced to that of merely placating its constituency and reassuring it of the government's good intentions. The party can neither initiate nor block policies, and it can never play anything more that ancillary policies." $\$ 2$

The Chinese dilemma also concerns cultural assimilation and acculturation, as the identities "us vs them" or "pribumi vs immigrants" continue to become more and more juxtaposed and entrenched. ${ }^{83}$ This has even affected the interpretation national identity and citizenship. Quoting the feelings of one young Chinese Malaysian, Lin-Sheng writes:

" $\ldots$ the Chinese dilemma is that when we are abroad, we are Malaysians first and Chinese second, but at home, we are Chinese first and Malaysians second." $" 84$

Another Chinese Malaysian, Lim Kam Hing, also writes that affirmative action was needed at the time and that although MCA lost several of its central portfolios in the 1971 cabinet, particularly the Ministry of Trade and Industry, it did manage to keep Finance and Health, and the newer generation with MCA were forced to change their tactics from politics to small to medium trade and to shift their activities towards the grassroots level of society. ${ }^{85}$ However, quoting another Chinese leader, Lim Kam states that the NEP program was incapable of attaining national unity, and so in 1990, which should have marked the end of the NEP, a movement arose to promote eradication of the divide between the bumiputera and non-bumiputera. ${ }^{86}$

${ }^{82}$ Ye Li-Sheng, The Chinese Dilemma, $5^{\text {th }}$ edition, New South Wales Australia, East West Publishing, 2008, p. 55.

${ }^{83}$ Ibid., p. 82.

${ }^{84}$ Ibid., p. 137.

${ }^{85}$ See Lim Kam Hing, "The Bumiputera Policy: Chinese Views and Perspectives," in Mason \& Ariffin (eds.), The 'Bumiputera Policy,' pp. 346-7.

${ }^{86}$ Ibid., p. 353. 
Similar criticism was levelled by Indian writers. Ramasamy, for instance, notes that native Malays held much the same position as Indian Malays before independence and at the time the NEP was introduced. The majority had been neglected and were living in poverty. He admits that initially the UMNO, MCA and MIC coalition was a place for Indians to negotiate and voice their aspirations, but eventually UMNO hegemony within BN saw an end to this. Ramasamy writes:

"However, the scenario changed with the formation of the $\mathrm{BN}$ and the emergence of UMNO as the most powerful and dominant party. It was the emergence of UMNO in championing Malay rights and privileges on the grounds of their bumiputera status that created problems for other ethnic political parties in the Barisan coalition. The new forms of politics that emerged did not totally discard the interests of non-Malays, but made them secondary to the larger interests of Malays. Therefore the kind of inter-ethnic bargaining and compromise that was so essential for the success for the earlier consociational model become less and less relevant under the hegemonic politics of Malays." ${ }^{\text {87 }}$

Besides MIC being too dependent on UMNO, there were also internal issues within MIC itself. The party became highly authoritarian, with leaders tending to neglect the interests of the poor in order to prioritise their own agendas. Consequently, Indians began to feel that the party did not represent their interests, even though MIC was in a position to make changes. ${ }^{88} \mathrm{~A}$ young Indian Malaysian executive and CEO of an independent online daily paper told how MIC was little more than a party owned by one person. For 20 years its chairman had never been replaced, and the entire party was centred around his interests alone. It was little surprise that he lost his seat in parliament in the 2008 election. ${ }^{89}$

According to Ramasamy, government contracts were always awarded to Malays close to the UMNO ruling elite. He explains:

"As long as Malay interests and concerns are going to be prioritized under the banner of Malay hegemony, it would be impossible for Indians to obtain a fair chance. The prominent role played by a handful of wealthy

${ }^{87}$ P Ramasamy, "Nation-Building in Malaysia: Victimization of Indians?" in Leo Suryadinata (ed.), Ethnic Relations and Nation Building in Southeast Asia: The Case of the Ethic Chinese (Singapore: ISEAS, 2004), p. 150.

${ }^{88}$ Ibid., 2004, p. 153.

${ }^{89}$ Interview with Prem. 
entrepreneurs would not make much difference to the overall progress of the community. It is not that Indians lack the necessary skills and knowledge, but it is the particular kind of racial politics in the country that prevents them from fully utilizing the opportunities." 90

Meanwhile, Jomo, evaluating the NEP in 1990, shows how any increase in prosperity was only a result of growth and productivity that was not accompanied by redistribution. He writes:

"It should also be recognized that much of the reduction in poverty has been due to economic growth and increased productivity more generally, rather than more equitable redistribution of economic resources, especially capital and land. Hence, without such redistributive measures, it is inevitable that measures aimed at reducing poverty are only likely to be marginally effective since poverty rights and the basically inequitable pattern of asset distribution are not to be tampered with by government policy." 91

Syed Husin Ali's critique is perhaps more fundamental, suggesting that the policy should not accord only with theories of economic growth, but should also regulate land reform. The current deputy chairman of PKR, wrote a stinging criticism in 1974 that led to his imprisonment under the ISA. He argued that even if the NEP was successful in channelling wealth and control of the national economy from ethnic Chinese to ethnic Malays, it would only be enjoyed by the elite, and would never eradicate poverty in villages. This was caused, amongst other things, because the government rejected the transferral of land ownership in land reform to achieve the NEP's real objective, and because of the ruling elite's "digressions". 92

\section{From Malay/non-Malay to Bumiputera/non-Bumiputera, An ethnic approach}

During the 1950s until several years after independence, there was a large Chinese population in Malaysia (45\%). This was before the inclusion of Sabah and Sarawak and before Singapore, with its Chinese

${ }^{90}$ Ramasamy, "Nation-Building in Malaysia", p. 156.

${ }^{91}$ Jomo, "Whither Malaysia’s New Economic Policy," p. 474.

${ }^{22}$ Syed Husin Ali, "Economic Growth, Stratification and Ethnicity," in Syeh Husin Ali, Ethnic Relations, pp. 23-7. 
majority, split. ${ }^{93}$ After these two events, the Chinese population fell to 26\%, with Malays constituting 53\%. ${ }^{94}$ There were several non-Muslim groups and indigenous peoples in Sabah and Sarawak (12\%), in addition to ethnic Indians and other very small minorities such as those of Portuguese descent. While these minority non-Muslim ethnic populations are concentrated in Sabah and Sarawak, the Chinese and Indians are spread widely. Today, Penang is the only Chinese majority state. ${ }^{95}$

These particular events in Malaysian history did not only influence the composition of Malaysia's population, but also had consequences for the categorisation of citizenship based on ethnicity and identity, as well as the fate of minorities. It has influenced the entire Malaysian political system and policymaking. ${ }^{96}$ Before the inclusion of Sabah and Sarawak and the loss of Singapore, the official title used for pribumi (native) Malays in the constitution (Federal Constitution 153[1]) and government programs was Melayu (Malay), which included indigenous peoples in the peninsula. There were four main conditions required to be Malay, including being Muslim, having proficiency in Malay, practicing Malay customary traditions, and being born in Malaya or Singapore or having Malay/Singaporean ancestors. ${ }^{97}$ This discourse was used within UMNO and in government policies. Clearly, elements of the Malay Supremacy policy were present long before independence, even though it was only in 1971 that the policy was intensified. However, after the inclusion of Sabah and Sarawak, the large population of non-Muslim natives in the two states meant that the discourse was insufficient when it came to including these populations as natives in the Malaysian political system. Thus the category Melayu, which initially only saw Muslims as natives, was extended to incorporate ethnic Malays, ethnic non-Muslims, and the indigenous peoples of Sabah and Sarawak, in addition to immigrants of

${ }^{93}$ Maznah Mohamad, "Politics of the NEP”, pp. 118-9.

${ }^{94}$ A number of scholars argue that the move to include Sabah and Sarawak and push Singapore out of the Federation of Malaysia was politically engineered to make ethnic Malays / pribumi the clear majority, in order to implement very strong pro-pribumi policies. See Ibid. p. 123.

${ }^{95}$ Ibid., pp. 118-9.

${ }^{96}$ Daniels, Building Cultural Nationalism, pp. 25-33.

${ }^{97}$ See Abdul Rahman Haji Ismail, "Bumiputera, Malays and Islam: A Historical Overview,” in Mason \& Ariffin (eds.), The 'Bumiputera Policy', p. 117. 
Malay blood, such as those from various regions in Indonesia and the Southern Philippines. The title Melayu was changed to bumiputera, as noted in the 1971 constitutional amendment, Article 153 (Act A30). ${ }^{98}$ The NEP policy, often referred to as Malay Supremacy is actually more correctly described by the term bumiputera Supremacy ${ }^{99}$ as state and government prioritising of the pribumi majority does not only involve Muslim citizens but also includes non-Muslim natives and those with pagan or polytheistic indigenous beliefs. Immigrant populations were also divided, with some falling under the Malay, now bumiputera, category such as those originating from regions that are now part of Indonesia (Minang, Bugis, Aceh and Java ${ }^{100}$ and others falling under the non-bumiputera category, including the usually Buddhist Chinese, and usually Hindu Indians.

In addition to the bumiputera/non-bumiputera polarisation, which some see as having created second class citizens (the non-bumiputera), inequalities have also emerged within the bumiputera, creating a group which some have labelled 'second class bumiputera.' This has primarily affected the non-Malay or non-Muslim bumiputera in the multiethnic and multiracial states of Sabah and Sarawak. It cannot be denied that they have suffered from economic and educational inequalities which have restricted their access to jobs, the economy and politics. This issue has been the subject of heated discussions between the government and the opposition concerning reinterpretation of the Federal system and economic distribution. There had indeed been positive effects for economic distribution for the pribumi under the NEP/NDP/NVP, but they were not enjoyed equally. In her analysis of the initial phase of the NVP and its effect on Sarawak, Madeline Berma concludes that:

"In Sarawak, it was the Malays and the Chinese who benefited the most from the economic growth during NEP and NDP period. Government policies appear to be biased against bumiputera minorities in public sector employment and business support... While an increasing number of bumiputera have entered the modern and attractive economic sectors in Malaysia, the fact remains that economic growth during the NEP and NDP periods did not equally benefit the majority of bumiputera minorities.

${ }^{98}$ See Shad Saleem Faruqi, "Affirmative Action Policies and the Constitution," in Mason \& Ariffin (eds.), The 'Bumiputera Policy', pp. 35-6.

${ }^{99}$ See Abdul Rahman Haji Ismail, "Bumiputera, Malays and Islam”, p. 118.

${ }^{100}$ See Daniels, Building Cultural Nationalism, p. 53-7. 
The bumiputera minority continues to predominate at the rural sector."101

A similar situation has emerged in Sabah. Kurus and Tangau write: "... one of the fundamental challenges that remains is the need to put in place additional 'enabling factors' that would provide all segments of society, but especially 'marginalised and disadvantaged groups' within the country equitable opportunity to equip themselves and contribute their fair share towards the realization of Vision 2020.

“... given their continued dominance among the poorer segment of society, their very weak presence in the economic and business spheres and their low educational attainment, the indigenous people of Sabah surely rank among the diminishing but still sizeable marginalized and disadvantaged of Malaysian society." 102

Mason and Jawan describe the fate of the Dayaks, one of the larger tribes in Sarawak:

"One major aim of the NEP, launched in 1971, was to uplift the socioeconomic standing of the Bumiputera communities, both Malay/Muslim and the non-Muslim, whose economic positions were historically inferior to the migrant Chinese. In this regard, the NEP has achieved significant success vis-à-vis the Malay... But the same could not be said of the other indigenous ethnic communities. It is especially true of Dayak communities in Sarawak; and it is this sense of discrimination and marginalisation that gave rise to dayakism... For a larger Bumiputera rubric, the Dayak felt themselves to be treated as second-class vis-à-vis the Malay-Muslim communities who wield political power in the state." ${ }^{103}$

Meanwhile Ongkili details the fate of the important Kadazandusun tribe in Sabah:

"Not much can be said about development of Kadazan bumiputeraism today, except to note that Kadazandusuns are increasingly less enamoured with the bumiputera status accorded them 40 years ago. There is growing

${ }^{101}$ Madeline Berma, "Towards the National Vision Policy: Review of NEP and NDP Among the Bumiputera Communities in Sarawak," in Mason \& Ariffin (eds.), The 'Bumiputera Policy', p. 250.

${ }^{102}$ Bilson Kurus \& Wilfred M Tangau, "Towards the National Vision Policy: Review of NEP and NDP Among the Bumiputera Communities in Sabah," in Mason \& Ariffin (eds.), The 'Bumiputera Policy', p. 280.

${ }^{103}$ Richad Mason \& Jayum A Jawan, “The Bumiputera Policy and 'Dayakism': An Interpretation,” in Mason \& Ariffin (eds.), The 'Bumiputera Policy', p. 190. 
disenchantment with the term as Kadazans no longer subscribe to the 'privileges analogous to the Malay' policy. Many in the community treat it with indifference, others tend to joke about it, hence the terms third class bumiputera, pseudo-bumiputera and bumiputera-celup." "The term 'minority bumiputera' has emerged over the past few years and has attracted considerable interest locally. Kadazan intellectuals have taken up the issue to try and find answers to disillusionment among Kadazans with the 'bumiputera policy'...."104

After such a lengthy discussion, an interesting question emerges in relation to Islamic law doctrine. Suppose that the situation presented above with all its complexities be interpreted in terms of the dhimmi and harbi categories of shari'ah or static and conventional Islamic law. The task is by no means easy. Bumiputera Superiority does not only include Muslims, as political demands and social developments required that the concept be modified and expanded. Also, non-Muslim bumiputera are not only 'people of the book' but also pagans/polytheists who, according to the Qur'an, are classed as mushrik and must be forced to submit to Islam. However, due to politico-historic factors and economic justice, they have been incorporated into the bumiputera category, and as such given priority in the Malaysian economic and political system (despite the inequalities they still face vis-à-vis Muslim bumiputera). If one asks this question in relation to the separation of Singapore from the Federation of Malaysia, does it mean that Singaporean non-Muslims, initially dhimmis in the Malaysian state, automatically became harbis after the split, and as such enemies upon which war may be waged? Of course not. Although both nations have a competitive relationship occasionally marked by tension, they have never waged war on one another and have always respected one another when they have been bound by their respective constitutions and international law.

This suggests that local political and economic realities as well as the international system have more influence on modern Muslim political and social structures, which may well instigate reformation or transformation (or whatever one wants to call it) of the highly static and conventional shari'ah doctrine, so that it can contribute to and help resolve some of the more concrete problems present in contemporary social life.

${ }^{104}$ James F Ongkili, “The Problem of Kadazandusun Bumiputeraism: Promises, Privileges and Politics," in Mason \& Ariffin (eds.), The 'Bumiputera Policy', p. 206. 


\section{Recent Debate on People's Supremacy vs One Malaysia}

In his speech prior to announcing new cabinet members of 2008, PM Mohd Najib Tun Abdul Razak, stated:

"As I have spoken to people over recent days, I have seen and heard a desire for renewal and change. This will be a government which will respond to the needs of the Rakyat, and prepared to serve future generations." "I am proud to have selected 28 men and women... They reflect the strength and diversity of the $\mathrm{BN}$ coalition, which is representative of all Malaysians and all parts of our country... One Malaysia."”105

He concluded:

"I have also appointed a minister in charge of Unity within the Prime Minister's Department, concurrent with his responsibility for Performance Management. This new Portfolio will adopt creative approaches towards promoting national unity, in line with the concept of One Malaysia, People First, Performance Now. Economic recovery and building long-term prosperity are the top priorities of the government. As such, I will lead out government's efforts with an experienced, proven economic team working for Malaysia." 106

This quote is indicative of how serious BN-UMNO apparently is under the leadership of Malaysia's sixth prime minister to implement reformation and to respond to the opposition's challenge and the people's demands. In addition to promising to implement fundamental and drastic changes, Najib introduced the new slogan, "One Malaysia", accompanied by propaganda advertising the new government's "One Malaysia, People First, Performance Now" platform. ${ }^{107}$

Najib spoke about not only of his promises but of the policies he would implement. He announced, for instance, that in 2010 for the first time ever he would grant "Wang Ehsan", a kind of compensation to Kel-

${ }^{105}$ Mohd Najib Tun Abdul Razak (Malaysian PM), Moving Abead (Selangor: MPH Group Publishing, 2009), p. 1.

106 Ibid., p. 4.

${ }^{107}$ Advertising was massive, from stickers on public transport and private vehicles, billboards on main roads, signs on shops and houses, in addition to advertising in all forms of media (print, electronic and online). Ads were even played in cinemas before movies commenced, several mass events were held at all levels, including national and state. The PM himself gave fiery speeches at these events, the first held in Perak on 18 October 2009 and attended by more the 50,000. The opposition criticized the large turnout, arguing that they were paid to attend. New Strait Times, 18/10/09. 
antan and Trengganu for their oil production. ${ }^{108}$ The construction budget for Sabah and Sarawak, the two poorest and most underdeveloped states in Malaysia that had, nevertheless, given significant support to UMNO, would be increased. ${ }^{109}$ Najib also announced that September 6, marking the incorporation of Sabah and Sarawak, would be a National Holiday as of $2010 .{ }^{110}$ In addition, Najib promised clean water and electricity for $90 \%$ and $95 \%$ of households respectively in the two states as of $1212 .{ }^{111}$ For poor Indians who voted for PKR, Najib promised a rather large budget to eradicate poverty and construct houses.

Many times throughout his speech Najib spoke of how UMNO was "prepared to change", and how it would push the other parties in the coalition to do likewise. Within UMNO, Najib altered the method of political recruitment by initiating open competition at all levels in response to criticism that appointment of committee members and MPs was dependent on bribery at all levels. Political leaders in the regions would be unable to quietly appoint cronies, relatives or anyone with a large enough bribe. Rather, anyone wanting to buy a position would require so much money it was no longer feasible to do so, as the number of people now involved in the process was much larger. ${ }^{112}$ Najib also argued that $30 \%$ of new recruits to the military academy should be non-Malay to counter Malay dominance in the institution. ${ }^{113}$

However, the fundamental problem BN currently faces, it seems, is that $\mathrm{UMNO}$ is running alone in the coalition, not only in gaining benefits from monopolistic and risky government projects, but also in their acquisition of seats in the general election. Despite the significant decrease in the number of votes $\mathrm{BN}$ managed to secure as a coalition, UMNO more or less maintained its representation while the other parties in the coalition suffered huge losses in parliament. Of the $63.1 \%$ the coalition secured, UMNO secured 35.6\%, MCA 6.8\%, MIC 1.4\%, PGRM 0.9\%

${ }^{108}$ New Straight Times, 05/11/09

${ }^{109}$ Nearly all electorates in the two states were under UMNO/BN control. Bernama News Office, 12/09/09.

${ }^{110}$ Bernama News Office, 19/10/09.

${ }^{111}$ The Edge Online News, 27/07/09, accessed 15/01/10.

112 www.umno-online.com, 19/10/09, accessed 17/01/10.

113 Bernama News Office, 15/01/10. 
and other small parties particularly from Sabah and Sarawak won $18.5 \% .{ }^{114}$ However, in order to restore its reputation and regain the trust of the people and other members of the coalition, it seems that UMNO must avoid the stereotype of being defensive and exploiting tensions between bumiputera/non-bumiputera. This is no easy task if only artificial measures are taken to create a public image without it being accompanied by concrete changes that are experienced directly by the people. On the need for UMNO to change its image Azly writes:

"These are burning questions as we become more mature about the 13 May 1969 incident. Students of nationalism would agree that UMNO does not have an ideology except to sustain its elusive political superiority via the reproduction of the marginalized forever enthralled to power and coercion." "Even 'Barisan National' (National Front) is elusive. The coalition is just surviving and clinging to power by all means. Its survival lies in the way people are divided, conquered and mutated into 'post industrial tribes'..."115

Despite all BN's promises for change, PR still feels it is too little too late. The opposition proposed at least four fundamental changes. First was a completely new reinterpretation of the exact form the Federation would take so that it be fairer for different regions and political and cultural groups. For PR, the current Malaysian Federation is a federation only in appearance as it is actually rather centralistic. ${ }^{116}$ This is apparent, for instance, from the uneven distribution of taxes and revenue from the oil industry. The centre has complete control over the distribution and unsurprisingly gains a far larger portion. It is often the case that development in opposition-controlled states is delayed as the centre holds back on funding. Clearly, redistribution does not follow the "Wang Ehsan/Goodwill money" concept, a concept that is supposed to indicate the good intentions and generosity of the centre, as it should. For the

${ }^{114}$ Saravanamuttu, "A Tectonic Shift in Malaysian Politics," p. 53.

115 Azly Rahman, "The 'New Bumiputera' as Pedagogy of Hope and Liberation: Teaching the Alternative Malaysian Ethnic Studies," in Lim Teck Ghee et. al., Multiethnic Malaysia, p. 436.

${ }^{116}$ Kok Wah calls Malaysia the most centralistic Federation in the world. For an analysis of the weaknesses and demands for change of the Malaysian Federation see Francis Loh Kok Wah, "Restructuring Federal-State Relations" in Francis Loh Kok Wah, Old Vs New Politics in Malaysia: State and Society in Transition (Petaling Jaya: SIRD, 2009), pp. 3-20. 
opposition, each state has the right to obtain a portion of tax and oil revenue, and as such it is the centre's obligation to distribute both fairly, which would see many states obtain much larger royalties than they currently do. Thus, reinterpretation of the Federal system would necessarily involve altering distribution of taxes and royalties from the oil industry (20\% for states). ${ }^{117}$

PR's second proposed change is to do away with the Bumiputeral Malay Supremacy policy and replace it with the People's Supremacy, a concept that relies on ability, fair competition or meritocracy and open tenders, but that continues to prioritise and act affirmatively to benefit the poor (based on needs and not ethnicity or political affiliation). PR has been relatively consistent in applying this concept in the states currently under its control. ${ }^{118}$

Thirdly, PR proposes a program to gradually introduce a dual party system in Malaysia. Although small parties are still allowed to operate, PR would see the creation of two large parties, but not in the current form, to balance power more equally. For this PR held a special symposium facilitated by the PKR's think tank to explore ideas and formulate a strategy in preparation for the PR Convention. ${ }^{119}$ The PR Convention gave three members the opportunity to present speeches on different topics to political party chairmen at the state level, ulama (except for DAP), intellectuals, youth, women, technocrats, and bureaucrats. PR also promised to annul all draconian acts in addition to the Biro Tata Negara (BTN or National Civics Bureau) course—a kind of ideological

117 Anwar Ibrahim's speech as leader of the PR coalition during the first Convention of Pakatan Rakyat, 19 December 2009, Selangor. See also "Memahami Wang Ehsan \& Perlanggaran Perjanjian Persekutuan," at http://www.anwaribrahimclub. com/2009/11/memahami-wang-ehsan-perlanggaran-perjanjian-persekutuan/, accessed $15 / 01 / 10$.

${ }^{118}$ According to Yusmadi, analysis by the State Auditing Agency of the first year of the new government after the election, those states under PR control (Penang, Selangor, Kelantan and Kedah) had the highest transparency, efficiency and least corruption. Interview with a PKR MP from Penang, Yusmadi Yusoff, 14 December 2009. However, the analysis was only of the first year and, Yusmadi continued, there were still a lot of challenges PR would face in maintaining and increasing their positive image in the wider society in the coming years.

119 Anwar Ibrahim's opening speech at the symposium and interview with the director of the Institute for Policy Studies, Khalid Jafar, 19 November 2009. 
indoctrination enforced by the current government which all students and civil servants are required to follow. ${ }^{120}$ However, PR would continue to maintain a federal system, with the King as ultimate ruler, Islam the official religion, and Malay the official language. ${ }^{121}$

Such radical changes have, according to informers within PKR ranks and within PR in general, made the coalition careful in the way they propose such changes, as they still lack sufficient political funds. PKR, for instance, needs to win over at least $50 \%$ of voters of Malay ethnicity formerly loyal to the government. If able to do so, PKR can then assertively and openly push for more radical changes. "We are still anticipating the support we will gain in the 2004 election," Yusmadi said. ${ }^{122}$ This, he added, would require maintaining the balance and mutual understanding within the PR coalition which to date, at least according to the first PR Convention, seems to be quite solid.

\section{F. Conclusion: Waiting for a New Nation?}

Malaysia is currently facing significant demands for fundamental change in management of identity, ethnicity and minorities, which has implications for political and economic justice as it requires ignoring differences based on ethnicity, skin colour, and religion, and eradicating the discrimination which has become a fundamental part of the Malaysian political system. If one looks at the issues being discussed in the public sphere and the substance of the opposition's demands, this push for change is clearly here to stay. These demands for change cannot be avoided, as they represent awakened awareness amongst those that have been oppressed, and are also part of a global trend that has accompanied democratisation and globalisation. In Malaysia the fundamental demands

${ }^{120}$ According to Khalid Jafar, Selangor has already begun to remove the requirement for students and civil servants to attend BTN indoctrination sessions in realization of PR's promise and strong desire for reformation. Interview with Khalid Jafar, 21 December 2009. For a short and comprehensive discussion of the BTN see Azly Rahman, "On the Problem of 'Ketuanan Melayu' and the Work of the Biro Tata Negara," in Lim Teck Ghee et. al., Multiethnic Malaysia, pp. 271-87.

${ }^{121}$ All of PR's promises and plans were detailed in the written draft "The First Convention of Pakatan Rakyat" 19 December 2009 in the MBSA Shah Alam Auditorium, Selangor.

${ }^{122}$ Interview with Yusmadi Yusoff. 
for radical change include new interpretation of the federal system including granting $20 \%$ in royalties to states from taxes and oil revenue; abolition of the Bumiputera Supremacy policy and its replacement with the People's Supremacy concept which; planned annulment of the draconian acts which have to date protected the status quo; as well as introduction of a dual party system which would allow voters to punish parties ignoring their aspirations, which in turn would help avoid the current situation where the status quo is maintained over long periods of time. Just how strong the people's aspirations for such change are, is apparent in the rather drastic increase in support of the opposition.

In addition, the willingness of the current $\mathrm{BN}$ government to gradually but fundamentally correct its policies to improve economic redistribution and to eradicate racially and ethnically based politics, and its promise of greater openness and freedom further indicates the extent to which the people and the opposition are able to make their aspirations heard. Similarly, the care now being shown towards Indians, the majority of whom are poor and discriminated against, and the attention given to the poorest and most backward of states such as Kelantan, Sabah and Sarawak, is a direct result of the power behind the debate and challenges presented by the opposition.

The opposition's victory in the coming election is not, by any means, the only or best measurement of how successful this change has been. Perhaps a more important measurement lies in the change itself and the ability to achieve equality of citizens without discrimination in regards to citizenship and the political system, as well as fair economic redistribution. It is largely irrelevant who implements the change. However this requires a system willing to implement change, and the opposition's radical proposals must be used to measure this. New interpretation of the federal system, eradication of the Bumiputera Supremacy concept through its removal from articles in the constitution, and annulment of the draconian acts that have been used to prop up the status quo, can all be used as a primary measurement of the determination for change. If these three things can be achieved, it is clear that the opposition desires more than simply taking control of government and maintaining the old system. If these three things can be achieved, it becomes possible for Malaysians, no matter their ethnicity or ancestry, to begin forming "a new 
nation." This new nation would be one without discrimination, without ethnic divisions, but with relative freedom and openness. It would be as one scholar puts it as "a new Bumiputera", a definition that carries no connotations of discrimination against specific groups or ethnicities, but protects and embraces all citizens without exception. ${ }^{123}$ Writing after the 2008 election, Azly stresses:

"The old concept of 'Bumiputera' needs to be reconstructed so that we will have a better foundation in preparation for a redefinition in the Federal Constitution - so that the constitution can now protect all rather that the few. Isn't democracy for the powerful few only good for plutocracy? Who is a 'Bumiputera'? After some 50 years this term should have evolved and changed. The base and suprastructure, the ideology and material foundation, and the body and spirit of this nation state called Malaysia have changed. ${ }^{124}$

To do this, in light of the many policies that still remain, such as the 'centralistic' federation system, Bumiputera Supremacy, and the well-entrenched draconian acts, requires sufficient political strength, greater social participation and leadership of integrity. A balance in political strength between two parties or two coalitions in the future may well symbolise the path to such change. On the other hand, from the perspective of Islamic scholarship, the reality in Malaysia (and possibly also in other places) and the fundamental changes hoped for, we are challenged to reinterpret the construction and relationship between the rather quite dynamic concepts of Islam, the state and society. In fact, we are even challenged to reinterpret the almost untouchable and taboo concepts of dhimmi and harbi. No matter the strength these two concepts have as doctrine, they both shift and seem to progress as they adapt to social movements both within Muslim societies and from outside influences. We must continue to open up this kind of "official closed corpus" Pandora's Box, to borrow Arkoun's word for the mushaf Qur'an, ${ }^{125}$ if necessary by force, and then display its contents to the wider community in order to achieve Islam's ultimate goal of justice.

${ }^{123}$ See Azly Rahman, “The 'New Bumpiputera' as Pedagogy of Hope and Liberation: Teaching the Alternative Malaysian Ethnic Studies," in Lim Teck Ghee et al., Multiethnic Malaysia, pp. 429-46.

${ }^{124}$ Ibid., p. 439.

${ }^{125}$ Mohammed Arkoun, "Rethinking Islam Today,” pp. 18-39. 


\section{BIBLIOGRAPHY}

Ali, Syed Husin, Ethnic Relations in Malysia: Harmony and Conlict, Kuala Lumpur: SIRD, 2008.

Arkoun, Mohammed, "Locating Civil Society In Islamic Contexts" in Sajoo, Amyn B. (ed.), Civil Society in The Muslim World, Contemporary Perspectives, London, I.B. Tauris Publishers, 2002.

----, "Rethinking Islam Today,” ANNALS, AAPSS, 588, July 2003.

Badawi, Dato' Seri Ahmadullah Ahmad, Islam Hadhari Approach Towards a Progressive Islamic Civilisation, Kuala Lumpur: Department of Islamic Development Malaysia (JAKIM), 2007.

Beng, Ooi Kee, Johan Saranananmuttu and Lee Hock Guan, March 8 Eclipsing May 13, Singapore: ISEAS, 2008.

Bengio, Ofra Bengio and Ben-Dor, Gabriel (eds), Minorities and the State in the Arab World, Colorado: Lynne Riemer Publishers, Inc., 1999.

Daniels, Timothy P., Building Cultural Nationalism in Malaysia: Identity, Representation, and Citizenship, New York: Roudledge, 2005.

Eminov, Eli, Turkish and Other Muslim Minorities of Bulgarian, London: Hurst and Company in Association with the Islamic Council, 1997.

Fadl, al-Khaled Abou, "Islamic Law and Muslim Minorities: The Juristic Discourse on Muslim Minorities from $8^{\text {th }}$ to $17^{\text {th }}$ Century CE / 2 th to $11^{\text {th }}$ Century Hijrah," Singapre, MUIS Occational Papers Series, 2006.

Fattāni, al-Ismail Lutfi, Ikbtilaf al-Där wa-Athäruh fill-Hukm al-Munākahăt wa'l-Mu'ámalāt, Saudi Arabia: Dār al-Salām, 1990.

Gans, Chaim, The Limits of Nationalism, Cambridge: Cambridge University, 2003.

Ghee, Lim Teck, and Alberto Gomes, and Azly Rahman (eds.), Multiethnic Malaysia: Past, Present and Future, Kuala Lumpur: SIRD, 2009.

Jomo, K.S., "Whither Malaysia's New Economic Policy?," in Pacific Affairs Journal, Vol. 63, No. 4 (Winter, 1990-1991), pp. 469-99.

Kamali, Mohammad Hasyim, Civilization Renewal: Revisiting the Islam Hadhari Approach, Kuala Lumpur: IAIS, 2nd rev. ed., 2009.

Kymlicka, Will, Multicultural Citizenship: A Liberal Theory of Minority Rights, 
Oxford, Oxford University Press, 1995.

Li-Sheng, Ye, The Chinese Dilemma, $5^{\text {th }}$ edition, New South Wales Australia: East West Publishing, 2008.

Marican, Pawancheek, Anwar on Trial, in the Face of Injustice, Kuala Lumpur: GerakBudaya Interprise, 2009.

Martin, Richard C., "From Dhimmis to Minoriteis: Shifting Constructions on the non-Muslim Other from Early to Modern Islam" in Maya Shatzmiller (ed), Nationalism and Minority Identities in Islamic Society, Quebec Ciewty: McGill-Queen University Press, 2005.

Mason, Richard and Ariffin S.M. Omar, The 'Bumiputera' Policy Dynamic and Dillemmas', Pulau Pinang: Penerbit Universiti Sains Malaysia, 2005.

Mimmy, al-Hasan, Abl Dhimmah fi'l-Hadarah al-Islämiyah, Bairut: Dār al'Arab al-Islāmy, 1998.

Mohamad, Mahathir bin, The Malay Dilemma (With A New Preface), Singapore: Matshall Cavendish Editions, 2008.

Mutalib, Husin, Islam in Malaysia: From Revivalism to Islamic State, Singapore: Singapore University Press, 1993.

----, Islam Etnisitas: Perspektif Politik Melayu, Jakarta: LP3S, 1995. Natan, K.S. and Kamali, Mohammad Hashim (eds.), Islam in Soueast Asia: Political, Social and Startegic Challenges for the 21st Century, Singapore: ISEAS, 2005.

Nisan, Mordechai, Minorities in the Middle East, A History of Struggle and Self-Expression, 2nd ed., North Carolina: McFarland and Company Inc., 2002.

Noor, Fariz A., Islam Embedded: The Historial Develoment of the Pan-Malaysian Islam Party PAS (1951-2003), Volume 1 and 2), Kuala Lumpur: Malaysian Sociaological Research Institute, 2004.

Parekh, Bhikhu, Rethinking Multiculturalism: Cultural Diversity and Politial Theory, London: Macmillan Press, 2000.

Peleg, Ilan, Democratizing the Hegemonic State: Political Transformation in the Age of Identity, Cambridge: Cambridge Univerity Perss, 2007.

Poulton, Hugh and Taji-Farouki, (eds.), Muslim Identity and the Balkan State, London: Hurst and Company in Association with the Islamic Council, 1997. 
Poulton, Hugh, "The Muslim Experience in the Balkan State, 1919-1991," Association for the Study of Nationalities, Nationalist Papers, Vol. 28, No. 1, 2000.

Qarḍawi, al-Yūsuf, Ghair al-Muslimin fi'-Mujtami' al-Islāmy, Kairo: Maktabah Wahbah, 1992.

Razak, Moh Najib Tun Abdul, Moving Ahead, Selangor: MPH Group Publishing Sdn Bhd, 2009.

Senturk, Recep, "Minority Rights in Islam: From Dhimmi to Citizen," in Hunter, Shireem T. and Malik, Huma (eds), Islam and Human Rights: Advancing A U.S. - Muslim Dialogue, Washington DC: CSIS, 2005.

Shatzmiller, Maya (ed.), Nationalism and Minority Identities in Islamic Society, Quebec Ciewty: McGill-Queen University Press, 2005.

Siddiqi, Muhammad Yasin Mazhar, The Prophet Muhammad SAW: A Role Model for Muslim Minorities, Leicestershire: The Islamic Foundation 2006.

Soong, Kua Kia, May 13: Declassified Document on the Malaysian Riots of 1969, Kuala Lupur: Suaram Komunikasi, 2007.

Wah, Francis Loh Kok, Old vs New Politics in Malaysia: State and Society in Transition, Kuala Lumpur: SIRD, 2009.

Waters, Timothy William, "Reconsidering Dhimmah as a Model for a Modern Minority Rights Regime (with Some Notes on the Implications for Human Rights)", Indiana University School of Law - Bloomington, available in http://papers.ssrn.com/sol3/papers. cfm?abstract_id=941553. Access 06/10/09

Watson, Michael (ed.), Contemporary Minority Nationalism, London: Routledge, 1990.

Ye'or, Bat, The Dhimmi: Jews and Christians Under Islam, New Jersey: Associated University Presses, 1985. 